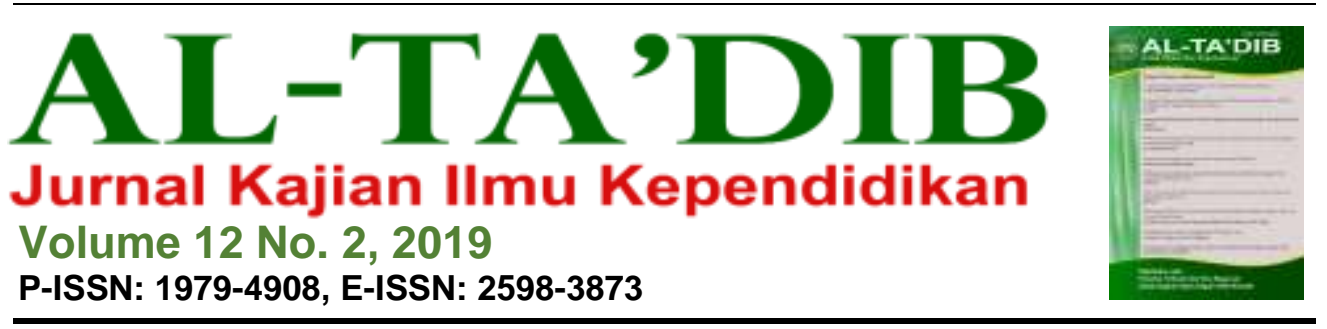

\title{
Hubungan Kepemimpinan Kepala Madrasah dan Kemampuan Mengajar Guru dengan Pembelajaran Siswa
}

\section{Samsuri $^{1}$}

${ }^{1}$ Institut Agama Islam Negeri Kendari, Kendari, Indonesia. E-mail: samsuri7180@gmail.com

\begin{tabular}{l} 
INFORMASI ARTIKEL \\
\hline Kata Kunci: \\
Kepemimpinan kepala \\
madrasah; kemampuan \\
mengajar guru; kualitas \\
pembelajaran siswa \\
Cara Mensitasi: \\
Samsuri. (2019). \\
Hubungan Kepemimpinan \\
Kepala Madrasah dan \\
Kemampuan Mengajar \\
Guru dengan Pembelajaran \\
Siswa. Al-Tadib:Jurnal \\
Kajian Ilmu Kependidikan, \\
12(2), 259-276. \\
DOI: \\
http://dx.doi.org/10.31332/ \\
atdbwv12i2.1316 \\
\hline
\end{tabular}

\begin{abstract}
ABSTRAK
Penelitian ini memberi gambaran tentang kepemimpinan kepala madrasah tsanawiyah (MTs), kemampuan mengajar guru MTs, kualitas pembelajaran siswa, dan hubungan kepemimpinan kepala madrasah dan kemampuan mengajar guru dengan kualitas pembelajaran siswa. Penelitian ini menggunakan metode ex post-facto dengan sampel berjumlah 106 siswa yang diambil menggunakan teknik proporsional random sampling. Hasil penelitian menunjukkan bahwa kepemimpinan kepala MTs di Kota Kendari memperoleh kategori baik, kemampuan mengajar guru tergolong kategori, dan kualitas pembelajaran siswa dalam kategori baik. Berdasarkan hasil analisis statistik inferensial terdapat hubungan yang positif dan signifikan antara kepemimpinan kepala madrasah dan kemampuan mengajar guru dengan kualitas pembelajaran siswa MTs di Kota Kendari.
\end{abstract}




\begin{tabular}{l} 
ARTICLE INFO \\
\hline Keywords: \\
Madrasah principal's \\
leadership; teacher \\
pedagogical competence; \\
quality of student learning \\
How to cite: \\
Samsuri. (2019). \\
Hubungan Kepemimpinan \\
Kepala Madrasah dan \\
Kemampuan Mengajar \\
Guru dengan Pembelajaran \\
Siswa. Al-Tadib:Jurnal \\
Kajian Ilmu Kependidikan, \\
12(2), 259-276. \\
DOI: \\
http://dx.doi.org/10.31332/ \\
atdbwv12i2.1316 \\
\hline
\end{tabular}

\begin{abstract}
This research examines the leadership of madrasah tsanawiyah's (MTs) principals, MTs teachers' pedagogical competence, the quality of students' learning, the relationship between principals' leadership and teachers' pedagogical competence with the quality of students' learning. This ex post facto research covered 106 students as sample using proportional random sampling technique. The results show that the leadership of MTs principals in Kendari is in good category, the teachers' pedagogical competence is good, and the quality of students' learning is categorized good. The result of inferential statistical analysis indicates a positive and significant relationship between the leadership of the school principal and the teachers' pedagogical with the quality of learning of the MTs students.
\end{abstract}

\title{
1. Pendahuluan
}

Sumber daya manusia yang berperan penting dalam pendidikan adalah kepala madrasah dan guru. Kepala madrasah memiliki tanggung jawab melakukan perbaikan dan peningkatan mutu pendidikan dan pengajaran. Di sisi lain, guru diharapkan mampu mengelola kelas sehingga tercipta proses pembelajaran yang bermutu. Tanpa mengabaikan faktor-faktor lain, guru dapat dianggap sebagai faktor utama yang paling menentukan terhadap meningkatnya mutu pendidikan (Nawawi, 2002). Hal ini menunjukkan bahwa kepala sekolah melalui proses kepemimpinannya dan guru sebagai seorang pendidik dan pengajar akan sangat menentukan terciptanya kondisi sekolah yang efektif. Sekolah yang efektif adalah sekolah yang memiliki mutu yang baik, yaitu siswa dengan kemampuan dan keterampilan sesuai dengan tuntutan dan keinginan masyarakat dalam rangka menjawab tantangan moral, mental dan perkembangan ilmu serta teknologi. Siswa yang bermutu adalah siswa yang memiliki kemampuan mengembangkan potensi dirinya sebagai kualitas pembelajaran di sekolah.

Akan tetapi, hasil pendidikan selama ini menunjukkan gejala penurunan kualitas baik dari segi hasil seperti yang ditunjukkan oleh hasil Ujian Akhir Nasional (UAN) maupun dari segi pembentukan sikap dan mental peserta didik. Kenyataan tersebut merupakan dilema pendidikan yang menggejala, termasuk di Kota Kendari. Rendahnya hasil UAS/UAN dan menurunnya nilai moral siswa di Kota Kendari merupakan masalah besar yang hingga saat ini 
belum terpecahkan. Sementara itu, upaya peningkatan kualitas kepemimpinan kepala madrasah/sekolah dan kemampuan mengajar guru terus diintensifkan melalui penataran, lokakarya, studi banding, dan akses kesempatan untuk melanjutkan pendidikan ke jenjang yang lebih tinggi. Kesenjangan ini melahirkan pertanyaan apakah kepemimpinan kepala madrasah tsanawiyah (MTs) dan kemampuan mengajar guru memiliki hubungan dengan kualitas pembelajaran siswa. Hal ini mencuat karena dalam proses pengelolaan madrasah, kepala MTs dan kemampuan mengajar guru adalah dua hal yang bertujuan untuk meningkatkan kualitas pembelajaran siswa.

Kepemimpinan mempunyai definisi yang beragam. Yukl (2017) mendefinisikan kepemimpinan sebagai proses memengaruhi orang lain untuk memahami dan menyetujui apa yang dibutuhkan dalam melaksanakan tugas dan bagaimana melakukan tugas itu, serta proses untuk memfasilitasi upaya individu dan kolektif guna mencapai tujuan bersama. Yukl mendefinisikan kepemimpinan secara luas dengan mempertimbangkan beberapa hal yang menentukan suksesnya usaha kolektif anggota sebuah organisasi untuk menyelesaikan tugas-tugas dalam mencapai tujuan bersama. Lebih lanjut ia menjelaskan bahwa definisi itu tidak hanya mencakup upaya untuk memengaruhi dan memfasilitasi pekerjaan kelompok atau organisasi yang sedang dilakukan tetapi juga memastikan bahwa semuanya dipersiapkan untuk memenuhi tantangan di masa depan. Pendapat di atas memiliki makna bahwa kepemimpinan adalah potensi seseorang untuk memengaruhi dan membujuk orang lain dengan berbagai interaksi untuk mencapai tujuan yang diinginkan. Sedangkan menurut Antonakis dan Day (2018), kepemimpinan adalah proses formal dan informal dalam memengaruhi untuk mencapai tujuan yang diinginkan antara pemimpin dan pengikut, kelompok pengikut, atau lembaga. Lebih jauh dijelaskan bahwa ilmu kepemimpinan adalah studi sistematis dari sebuah proses dan hasilnya, bagaimana proses ini dilakukan tergantung pada sifat-sifat dan perilaku pemimpin.

Berdasarkan makna etimologis dan beberapa pendapat tentang kepemimpinan di atas, dapat disimpulkan bahwa kepemimpinan adalah cara yang dilakukan pemimpin dalam memengaruhi dan membujuk orang lain dengan berbagai interaksi dengan maksud individu atau kelompok individu dalam sebuah organisasi dapat bekerja sama untuk mencapai tujuan bersama. Dalam bahasa Arab, kepemimpinan sering diterjemahkan sebagai al-riayah, al-imarah, al-qiyadah, atau al-zaamah. Kata-kata tersebut memiliki satu makna sehingga disebut sinonim atau murodif, sehingga bisa digunakan salah satu dari keempat kata tersebut untuk menerjemahkan kata kepemimpinan. Sementara itu, untuk menyebut istilah kepemimpinan pendidikan, para ahli lebih memilih istilah qiyadah tarbawiyah (Qomar, 2007). Dalam agama Islam, kepemimpinan begitu penting sehingga mendapat perhatian yang sangat besar. Begitu pentingnya kepemimpinan ini sehingga mengharuskan setiap 
perkumpulan untuk memiliki pimpinan, bahkan perkumpulan dalam jumlah kecil sekalipun. Hal tersebut sesuai dengan sabda Rasulullah Muhammad SAW "Dari Abu Said dari Abu Hurairah bahwa keduanya berkata, Rasulullah bersabda, "Apakah tiga orang keluar bepergian, hendaklah mereka menjadikan salah satu sebagai pemimpin." (HR. Abu Dawud).

Menurut Atmodiwirio (2000), kepemimpinan pendidikan memerlukan perhatian utama karena melalui kepemimpinan yang baik diharapkan lahirnya tenaga-tenaga yang berkualitas dalam berbagai bidang, baik sebagai pemikir maupun pekerja. Intinya, melalui pendidikan, tenaga yang berkualitas, siap latih dan siap pakai dapat disiapkan untuk memenuhi kebutuhan masyarakat. Efektivitas kerja dan tenaga yang berkualitas ditentukan oleh komitmen karyawan dengan cara menerapkan praktek sumber daya manusia yang maksimal dan daya saing lembaga dengan kepemimpinan yang baik (Hanaysha, 2016). Kepemimpinan kepala madrasah berperan sangat penting dalam rangka mengarahkan dan menggerakkan organisasi pendidikan untuk mencapai tujuan yang diharapkan. Kepala madrasah harus mampu memengaruhi personal di lingkungan madrasahnya pada situasi tertentu agar mereka melalui usaha kerjasama mau bekerja dengan penuh tanggung jawab dan ikhlas demi tercapainya tujuan pendidikan yang telah ditetapkan.

Madrasah adalah organisasi yang bersifat kompleks dan unik karena di dalamnya terdapat berbagai dimensi yang satu sama lain saling berkaitan dan saling menentukan. Unik karena madrasah sebagai sebuah organisasi memiliki ciri-ciri tersendiri yang tidak dimiliki oleh organisasi lain. Ciri yang menjadikan madrasah berbeda dengan organisasi lain adalah adanya proses belajar mengajar, tempat terselenggaranya proses kehidupan manusia. Karena sifatnya yang kompleks dan unik itu, madrasah sebagai organisasi memerlukan koordinasi yang tinggi dari seorang kepala madrasah sebagai pemimpin. Dengan kata lain, keberhasilan sebuah madrasah dalam menjalankan fungsinya akan sangat ditentukan oleh kepemimpinan kepala madrasah. Sebuah studi yang dilakukan oleh James, dkk (dalam Wahjosumidjo, 1999) menyimpulkan bahwa keberhasilan sekolah adalah keberhasilan kepala sekolah. Lebih jauh dijelaskan bahwa kepala sekolah dilukiskan sebagai orang yang memiliki harapan tinggi bagi para staf dan para siswa, kepala sekolah adalah mereka yang banyak mengetahui tugas-tugas mereka dan mereka yang menentukan irama bagi sekolah mereka (Wahjosumidjo, 1999).

Secara operasional, untuk mewujudkan produk madrasah menjadi tenaga-tenaga profesional, dibutuhkan figur kepala madrasah sebagai pemimpin yang handal. Figur pemimpin yang handal adalah kepala madrasah yang mampu melahirkan berbagai konsep pendidikan yang bisa mewadahi dan mengadaptasi perubahan sosial, ekonomi, dan teknologi, sehingga mereka siap menghadapi akibat terjadinya perubahan-perubahan dalam era 
globalisasi. Era globalisasi senantiasa menghadirkan perubahan-perubahan yang menyebabkan pola pikir dan pola hidup masyarakat sekarang turut berubah untuk melakukan penyesuaian. Hal ini juga berlaku dalam pendidikan madrasah, perubahan-perubahan itu harus dihadapi oleh kepala madrasah melalui strategi tertentu. Kepala madrasah harus mampu mentransformasikan organisasi madrasah melalui penguasaan tugas- tugasnya serta melaksanakannya dengan baik. Kemampuan yang besar itu tentu saja tergantung pada efek kepemimpinan kepala madrasah kepada seluruh stakeholder, kepala madrasah bertanggung jawab terhadap seluruh aktivitas madrasah, mengelola sumber-sumber daya yang ada baik sumber daya manusia, maupun sumber daya lainnya, agar semua itu dapat menunjang terciptanya efektivitas kerja dalam proses pencapaian tujuan pendidikan di madrasah.

Kemampuan guru sebagai tenaga profesional baik sebagai pendidik maupun pengajar merupakan kemampuan yang pada umumnya berhubungan dengan pengetahuan, keterampilan, dan sikapnya sebagai seorang guru. Guru sebagai pengajar perlu memiliki pengetahuan, keterampilan dan sikap tentang mengajar di kelas secara efektif dan efisien, khususnya kemampuan dalam hal merencanakan program pengajaran, merumuskan tujuan pengajaran, kemampuan dan penguasaan materi pelajaran, kemampuan memilih metode mengajar secara tepat dan kemampuan mengevaluasi hasil belajar.

Sehubungan dengan masalah di atas, Usman (2001) mengemukakan bahwa guru merupakan jabatan atau profesi yang memerlukan keahlian khusus sebagai guru. Pekerjaan ini tidak bisa dilakukan oleh orang yang tidak memiliki keahlian untuk melakukan kegiatan sebagai guru. Orang yang pandai berbicara dalam bidang-bidang tertentu belum dapat disebut sebagai guru. Untuk menjadi guru diperlukan syarat-syarat khusus, apalagi sebagai guru profesional yang harus menguasai seluk-beluk pendidikan dan pengajaran dengan berbagai ilmu pengetahuan lainnya yang perlu dibina dan dikembangkan melalui masa pendidikan tertentu atau pendidikan prajabatan.

Predikat baik seorang guru lebih banyak menyangkut segi profesionalnya, yaitu segi kemampuan mengajar sehari-hari. Gilbert H. Hunt (dalam Rosyada, 2004) menyatakan bahwa guru yang baik harus memenuhi tujuh kriteria, yaitu: sifat, pengetahuan, apa yang disampaikan, bagaimana mengajar, harapan dan reaksi guru terhadap siswa. Lebih lanjut Gilbert (dalam Rosyada, 2004) menjelaskan bahwa guru yang baik harus memiliki sifat-sifat antusias, stimulatif, mendorong siswa untuk maju, hangat, berorientasi pada tugas dan pekerja keras, toleran, sopan, dan bijaksana, bisa dipercaya, fleksibel dan mudah menyesuaikan diri, demokratis, penuh harapan bagi siswa, tidak semata mencari reputasi pribadi, mampu mengatasi stereotip siswa, bertanggung jawab terhadap kegiatan belajar siswa, mampu menyampaikan perasaannya dan memiliki pendengaran yang baik. 
Guru yang baik atau profesional adalah guru yang memiliki kemampuan dan kecakapan khusus dengan kriteria-kriteria tertentu yang berkaitan dengan keguruan, menguasai bahan/materi yang akan diajarkan, dan yang lebih penting adalah menjadi teladan bagi orang lain.Kemampuan mengajar yang diharapkan adalah yang berkaitan dengan masalah kemampuan yaitu kesanggupan dan kecakapan dalam perbuatan (performance) guru di dalam kelas, serta kemampuan sebagai konsep yang mencakup kognitif, afektif dan perbuatan (psikomotor). Nawawi (1982) mengemukakan bahwa pengetahuan dan pemahamannya tentang kompetensi guru akan mendasari pola kegiatannya dalam menunaikan profesinya sebagai guru. Kompetensi guru yang dimaksud antara lain mengenai kompetensi pribadi, profesi dan kemasyarakatan.

Abdurrahman (2003) menyatakan bahwa untuk melaksanakan tugas pokoknya, guru harus memiliki seperangkat kompetensi keguruan antara lain: (1) penguasaan materi bidang studi yang akan diajarkan; (2) pemahaman dan keterampilan mengelola kelas; (3) pemahaman dan kemampuan mengelola program pengajaran PBM dan sumber-sumber belajar; (4) keterampilan memilih, menyusun dan menggunakan berbagai media pengajaran; (5) kemampuan dan keterampilan memilih dan menggunakan model-model mengajar, strategi mengajar dan metode mengajar yang bervariasi; (6) kemampuan dan keterampilan menerapkan prinsip pengukuran dan penilaian; (7) pengetahuan, pemahaman, dan kemampuan menerapkan pengembangan sistem instruksional dalam PBM; (8) pengetahuan, pemahaman, kemampuan dan keterampilan menyusun dan melaksanakan program bimbingan dan konseling di sekolah.

Berbagai kemampuan guru tersebut di atas merupakan hal yang mutlak untuk dikuasai oleh setiap guru. Dari beberapa kemampuan tersebut, dapat disimpulkan bahwa jenis kemampuan yang harus dimiliki oleh setiap guru adalah memahami tujuan pendidikan, mampu membuat program pengajaran menguasai bahan yang akan diajarkan, memiliki keterampilan mengajar, mampu melaksanakan penilaian, mampu menganalisis hasil penilaian, mengenal layanan BP, dan memiliki keteladanan dalam setiap sikapnya. Dari beberapa kemampuan tersebut, menguasai bahan pengajaran merupakan poin yang sangat menentukan berhasilnya suatu proses belajar mengajar di kelas. Hal tersebut senada dengan penjelasan Suryadi dan Tilaar (1993), yang mengemukakan bahwa guru yang berkualitas adalah mereka yang memiliki kemampuan sesuai dengan profesinya, dan variabel kualitas kemampuan guru yang paling berpengaruh dan memberikan efek yang positif terhadap prestasi belajar murid adalah kemampuan menguasai bahan yang akan diajarkan. 


\section{Metode Penelitian}

Metode yang digunakan dalam penelitian ini adalah ex post-facto yang mengkaji hubungan kemampuan mengajar guru yang dilambangkan dengan $\left(\mathrm{X}_{2}\right)$ dan kualitas pembelajaran siswa yang dilambangkan dengan (Y). Penelitian dilakukan di empat madrasah tsanawiyah di Kota Kendari yaitu Madrasah Tsanawiyah Negeri I Kendari, Madrasah Tsanawiyah Negeri 2 Kendari, Madrasah Tsanawiyah Pesri Kendari dan Madrasah Tsanawiyah Labibia dengan jumlah sampel 106 orang siswa yang diambil dengan melakukan teknik proporsional random sampling.

Instrumen yang digunakan dalam penelitian ini adalah kuesioner, wawancara dan dokumentasi. Kuesioner digunakan untuk memperoleh data tentang kualitas pembelajaran siswa, kepemimpinan kepala madrasah dan kemampuan mengajar guru. Wawancara digunakan sebagai pelengkap data kuesioner. Adapun dokumentasi sebagai teknik pengumpulan data dipakai untuk memperoleh informasi tentang MTs di Kota Kendari, keadaan kepala madrasah, guru serta siswa berdasarkan klasifikasi dan penggolongannya.

Teknik pengumpulan data yang digunakan dalam penelitian ini adalah kuesioner tentang kepemimpinan kepala madrasah, kemampuan mengajar guru, dan kualitas pembelajaran siswa. Setelah data terkumpul, selanjutnya dilakukan analisis statistik dengan tujuan untuk menguji validitas dan reliabilitas. Angket dianggap valid apabila terdapat kesamaan antara data yang terkumpul dengan data yang sesungguhnya terjadi pada obyek yang diteliti. Angket dianggap reliabel apabila terdapat kesamaan data dalam waktu yang berbeda. Dalam pengambilan data melalui angket terlebih dahulu dilakukan uji coba instrumen penelitian (angket) untuk mengetahui validitas dan reliabilitasnya. Untuk mengetahui tingkat pencapaian hasil belajar siswa pada madrasah tsanawiyah di Kota Kendari, peneliti mengambil data nilai rapor siswa. Berdasarkan temuan penelitian diperoleh rentang nilai siswa berdasarkan jumlah dan nilai rata-rata dari bidang studi yang ada pada madrasah.

Teknik analisis data yang digunakan dalam menganalisis data penelitian ini ada dua. Pertama, analisis statistik deskriptif yaitu untuk memperoleh gambaran deskriptif setiap variabel. Setelah data terkumpul, terlebih dahulu dilakukan uji persyaratan analisis, yaitu uji normalitas. Kedua, analisis statistik inferensial dilakukan untuk menguji hipotesis penelitian dengan menggunakan uji regresi ganda. Seluruh analisis data mulai dari analisis validitas dan reliabilitas sampai regresi linear ganda dilakukan dengan bantuan program SPSS (Statistical Package for Social Sciences) Versi 12.0 dan digunakan pula Program Excel (tools). 


\section{Hasil dan Pembahasan}

\subsection{Hasil analisis statistik deskriptif}

Berdasarkan hasil analisis statistik deskriptif diketahui gambaran umum hasil penelitian tentang jenis kelamin responden, tingkat pendidikan responden, besarnya nilai rata-rata (mean), simpangan baku (standar deviasi), nilai maksimum, nilai minimum, modus dan median. Berdasarkan jenis kelamin, banyaknya responden yang penulis teliti adalah 70 orang guru sekolah madrasah tsanawiyah di Kendari yang terdiri atas 44 persen laki-laki dan 56 persen seperti pada Tabel 1.

Tabel 1 Responden berdasarkan jenis kelamin

\begin{tabular}{clcc}
\hline No & Jenis Kelamin & Frekuensi & Persentase \\
\hline 1 & Laki-laki & 31 & 44 \\
2 & Perempuan & 39 & 56 \\
\hline & Jumlah & 70 & 100 \\
\hline
\end{tabular}

Berdasarkan tingkat pendidikan terakhir, responden penelitian ini terbagi atas: jenjang diploma berjumlah 7 orang atau 10\%, sarjana (S1) berjumlah 62 orang atau $88,6 \%$, dan magister (S2) berjumlah 1 orang atau 1,4\%. Selengkapnya dapat dilihat pada Tabel 2.

Tabel 2 Gambaran responden berdasarkan tingkat pendidikan

\begin{tabular}{clcc}
\hline No & Pendidikan & Frekuensi & Persentase \\
\hline 1 & D3 & 7 & 10 \\
2 & S1 & 62 & 88,6 \\
3 & S2 & 1 & 1,4 \\
\hline \multicolumn{2}{r}{ Jumlah } & 70 & 100 \\
\hline
\end{tabular}

Selanjutnya untuk mengetahui gambaran hasil penelitian dari ketiga variabel penelitian akan dijelaskan sebagai berikut.

Kepemimpinan kepala madrasah $\left(X_{1}\right)$

Hasil analisis deskriptif diperoleh gambaran kepemimpinan kepala madrasah dengan skor maksimum 110 dan minimum 74 dengan rentang nilai variabel $\mathrm{X}_{1}$ adalah 36, rata-rata (mean) 94,94, median 95,00, mode 88 dan simpangan baku (standar deviasi) 8,526. Kecenderungan data variabel X1 lebih jauh dapat dilihat pada hasil analisis distribusi frekuensi berikut ini. 
Tabel 3 Distribusi frekuensi kepemimpinan kepala madrasah (variabel X1)

\begin{tabular}{cccl}
\hline Interval nilai & Frekuensi & Persentase & \multicolumn{1}{c}{ Kriteria } \\
\hline $74-80$ & 3 & 4,29 & Sangat tidak baik \\
$81-87$ & 9 & 12,85 & Tidak baik \\
$88-94$ & 22 & 31,42 & Sedang \\
$95-101$ & 17 & 24,29 & Baik \\
$101-110$ & 19 & 27,15 & Sangat baik \\
\hline Jumlah & 70 & 100 & \\
\hline
\end{tabular}

Data tabel tersebut di atas memperlihatkan bahwa dari 70 orang responden yang memberikan tanggapan terhadap kepemimpinan kepala sekolah, sebanyak 22 orang atau 31,42\% diantaranya menyatakan sedang, 19 orang atau $27,15 \%$ menyatakan sangat baik, 17 orang atau $24,29 \%$ menilai baik. Selanjutnya, terdapat 9 orang atau 12,85\% memilih tidak baik dan hanya 3 orang atau sebanyak 4,29\% menilai kepemimpinan kepala madrasah sangat tidak baik.

Secara ringkas deskripsi tentang kepemimpinan kepala madrasah tersebut di atas dapat dilihat pada histogram berikut:

Histogram kepemimpinan kepala madrasah $\left(\mathrm{X}_{1}\right)$

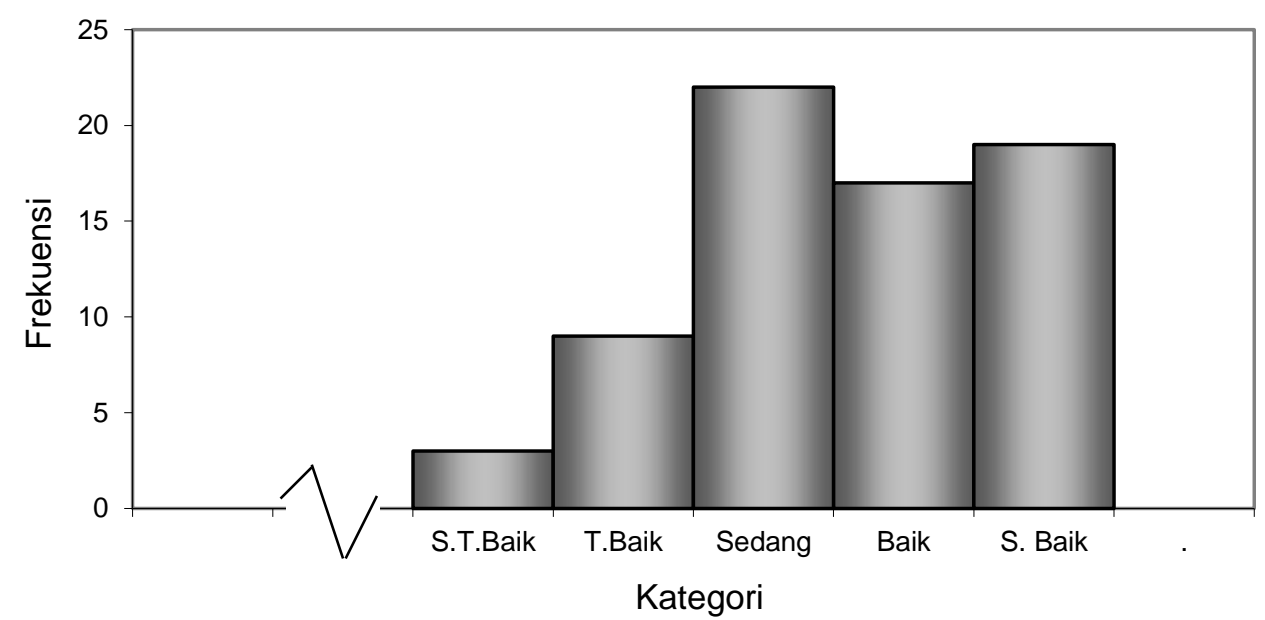

Gambar 1 Histogram kepemimpinan kepala madrasah

Kemampuan mengajar guru (X2)

Dari hasil analisis deskriptif kemampuan mengajar guru (variabel X2) diperoleh skor maksimum 135 dan minimum 89 dengan besar rentang nilai adalah 46, rata-rata (mean) 116,76, median 115,50, mode 112 dan simpangan 
baku (standar deviasi) 10,197. Kecenderungan data variabel X2 lebih jauh dapat dilihat pada hasil analisis distribusi frekuensi seperti pada tabel 4.

Tabel 4 Distribusi frekuensi kemampuan mengajar guru (variabel $\mathrm{X}_{2}$ )

\begin{tabular}{lccl}
\hline Interval nilai & Frekuensi & Persentase & Kriteria \\
\hline $89-97$ & 3 & 4,28 & Sangat tidak baik \\
$98-106$ & 4 & 5,72 & Tidak baik \\
$107-115$ & 28 & 48,75 & Sedang \\
$116-124$ & 17 & 24,28 & Baik \\
$125-135$ & 18 & 26,72 & Sangat baik \\
\hline Jumlah & 70 & 100 & \\
\hline
\end{tabular}

Data tabel tersebut di atas memperlihatkan bahwa dari 70 orang responden yang memberikan jawaban, ada 28 orang atau $48,75 \%$ memperoleh skor sedang, 18 orang atau $26,72 \%$ dalam kategori sangat baik, 17 orang atau $24,28 \%$ memperoleh nilai baik, 4 orang atau $5,72 \%$ dalam kategori tidak baik dan hanya 3 orang atau 4,28\% yang memiliki kemampuan mengajar sangat tidak baik. Hasil analisis tersebut menunjukkan bahwa secara umum bahwa kemampuan mengajar guru berada dalam kategori baik, walaupun terdapat sebagian kecil responden yang memiliki kemampuan mengajar yang sangat tidak baik.

Secara ringkas deskripsi tentang kemampuan mengajar guru tersebut di atas dapat dilihat pada histogram berikut:

Histogram kemampuan mengajar guru ( 2 2)

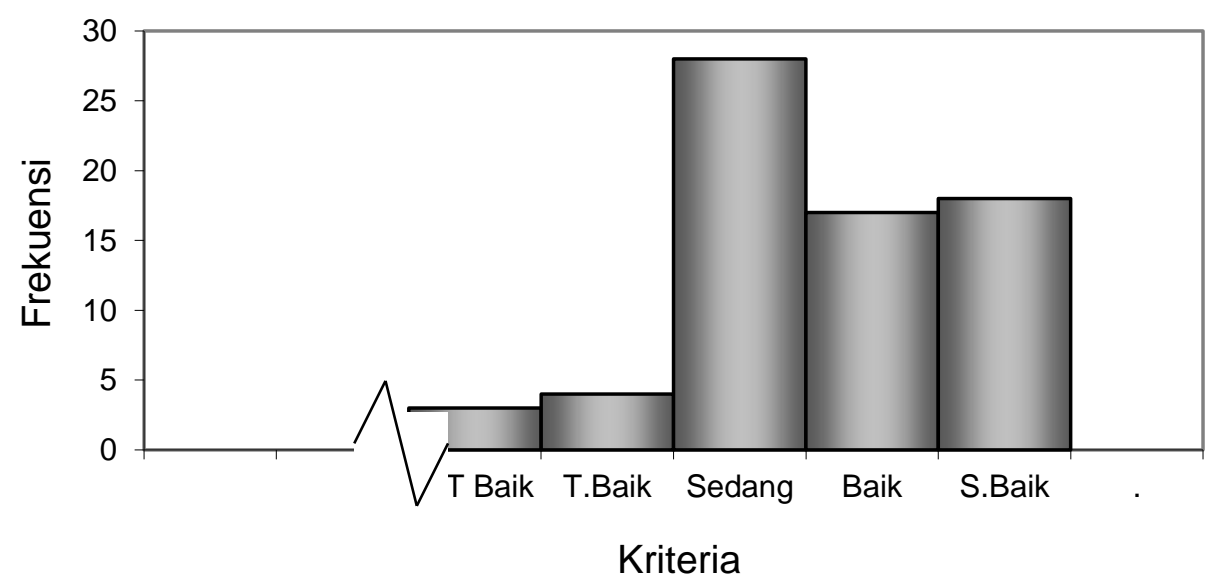

Gambar 2 Histogram kemampuan mengajar guru (X2) 
Kualitas pembelajaran siswa $(Y)$

Hasil analisis deskriptif kualitas pembelajaran siswa (variabel Y) diperoleh skor maksimum 135 dan minimum 69 dengan besarnya rentang nilai adalah 66, rata-rata (mean) 110,71, median 111,00, mode 102 dan simpangan baku (standar deviasi) 15,226. Kecenderungan data variabel Y atau kualitas belajar siswa lebih jauh dapat dilihat pada hasil analisis distribusi frekuensi seperti pada Tabel 5 .

Tabel 5 Distribusi frekuensi kualitas pembelajaran siswa (Y)

\begin{tabular}{cccl}
\hline Interval nilai & Frekuensi & Persentase & \multicolumn{1}{c}{ Kriteria } \\
\hline $69-82$ & 4 & 5,71 & Sangat tidak baik \\
$83-96$ & 7 & 10,00 & Tidak baik \\
$97-110$ & 21 & 30,00 & Sedang \\
$111-124$ & 25 & 35,72 & Baik \\
$125-140$ & 13 & 18,57 & Sangat baik \\
\hline Jumlah & 70 & 100 & \\
\hline
\end{tabular}

Data pada tabel tersebut di atas menunjukkan bahwa dari 70 orang responden yang memberikan jawaban, diperoleh 25 orang atau $35,72 \%$ menilai baik, 21 orang atau 30,00\% menyatakan sedang, 13 orang atau $18,57 \%$ menilai sangat baik, 7 orang atau $10,00 \%$ menilai tidak baik dan terdapat 4 orang atau $5,71 \%$ menganggap sangat tidak baik.

Histogram kualitas pembelajaran siswa $(\mathrm{Y})$

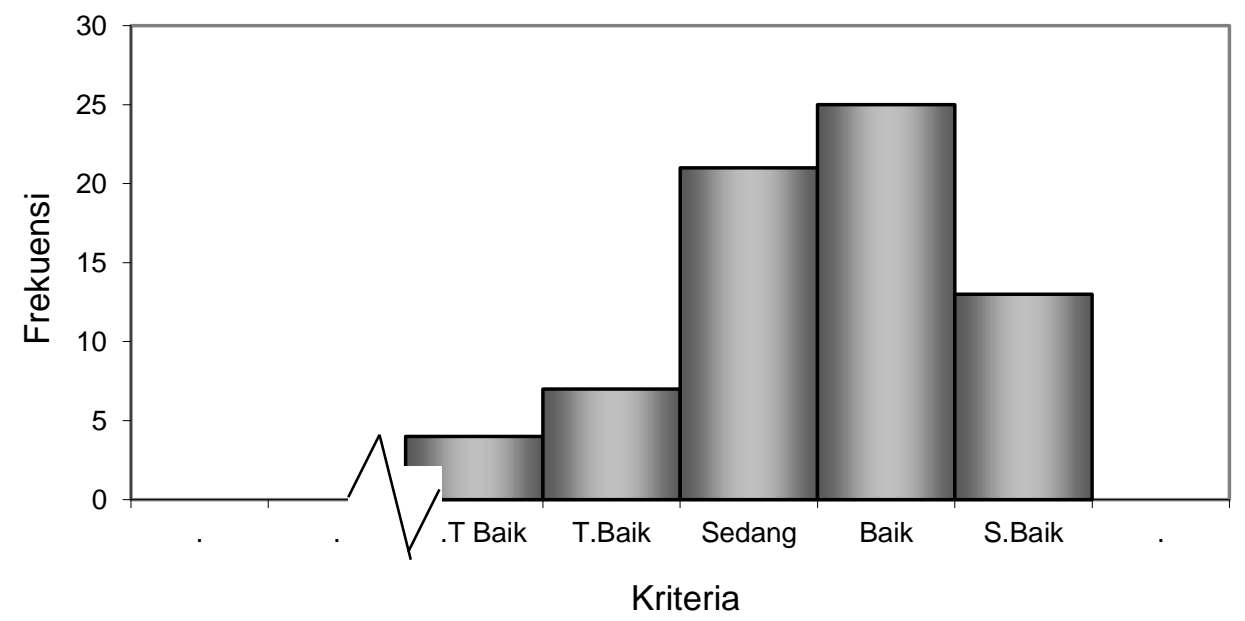

Gambar 3 Histogram kualitas pembelajaran siswa (Y) 
Hasil analisis pada Gambar 3 menunjukkan bahwa secara umum kualitas pembelajaran siswa berada dalam kategori baik, walaupun terdapat sebagian kecil responden yang menilai bahwa kualitas belajar siswa sangat tidak baik.

Hasil analisis deskriptif hasil belajar siswa diperoleh gambaran nilai siswa dengan skor maksimum 121 dengan nilai rata-rata maksimum 8,64. Nilai minimum 89 dengan nilai rata-rata 6,36. Rentang nilai adalah 32 atau 2,29 dari nilai rata-rata siswa, nilai rata-rata (mean) 7,16. Nilai median 100 atau 7,14. Nilai mode 96 atau 6,86 dan simpangan baku (standar deviasi) diperoleh nilai 7,86 atau 0,56. Kecenderungan data nilai hasil belajar siswa lebih jauh dapat dilihat pada hasil analisis distribusi frekuensi berikut ini:

Tabel 6 Distribusi frekuensi nilai hasil belajar siswa

\begin{tabular}{cccc}
\hline $\begin{array}{c}\text { Interval jumlah } \\
\text { nilai siswa }\end{array}$ & $\begin{array}{c}\text { Interval nilai } \\
\text { rata-rata siswa }\end{array}$ & Frekuensi & Persentase \\
\hline $89-92$ & $6,36-6,57$ & 7 & 18 \\
$93-98$ & $6,64-7,00$ & 9 & 23 \\
$99-101$ & $7,07-7,21$ & 9 & 23 \\
$102-106$ & $7,29-7,57$ & 8 & 20 \\
$108-121$ & $7,71-8,64$ & 6 & 16 \\
\hline Jumlah & & 39 & 100 \\
\hline
\end{tabular}

Data Tabel 6 di atas memperlihatkan bahwa dari 39 orang responden yang diambil data nilai rapornya, sebanyak 9 orang atau $23 \%$ diantaranya memperoleh nilai rata-rata antara 7,07-7,21;8 orang atau $20 \%$ memperoleh nilai rata-rata 7,29-7,57; sebanyak 6 orang atau $16 \%$ memperoleh nilai ratarata 7,71-8,64; dan 9 orang atau $23 \%$ memperoleh nilai rata-rata 6,64-7,00 dan hanya 7 orang atau sebanyak $18 \%$ memperoleh nilai rata-rata antara 6,36-6,57.

Hasil analisis tersebut memperlihatkan bahwa secara umum nilai ratarata hasil belajar siswa adalah 7-8 dan hanya sebagian kecil yang memiliki nilai rata-rata 6 . Hal ini menunjukkan bahwa hasil belajar siswa madrasah tsanawiyah di Kota Kendari termasuk dalam kategori baik.

Secara ringkas deskripsi tentang nilai hasil belajar siswa tersebut di atas dapat dilihat pada Gambar 4. 
Histogram nilai hasil belajar siswa

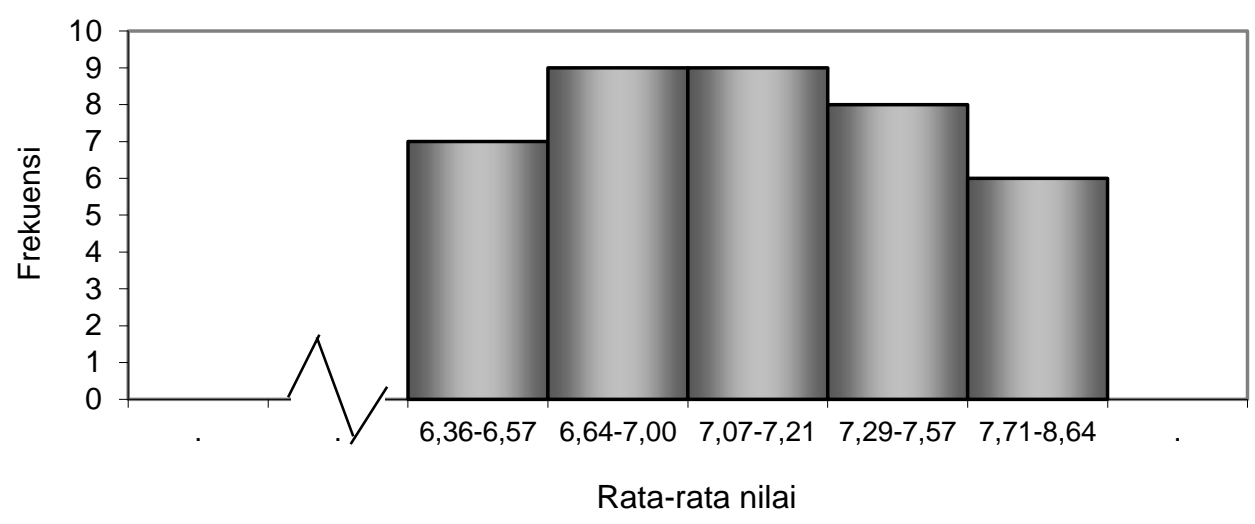

Gambar 4 Histogram nilai hasil belajar siswa

\subsection{Hasil analisis statistik inferensial}

Penyajian data hasil analisis statistik inferensial dimaksudkan untuk memberikan gambaran hubungan antar variabel penelitian yang diteliti. Berdasarkan analisis statistik inferensial diketahui hasil uji normalitas data, pengujian hipotesis dengan analisis regresi ganda, analisis korelasi parsial dan analisis varians.

\section{Hasil uji normalitas data}

Untuk mengetahui apakah data berdistribusi normal atau tidak, dilakukan uji normalitas data. Uji normalitas data dilakukan dengan menggunakan program SPSS dengan uji One-Sample Kolmogorov Smirnov. Sebuah hasil tes penelitian dinyatakan berdistribusi normal jika nilai probabilitas lebih besar dari 0,05 (nilai asym. Sig > 0,05). Dari hasil analisis data penelitian diperoleh bahwa kepemimpinan kepala sekolah adalah 0,624, kemampuan mengajar guru sebesar 0,568 dan kualitas pembelajaran siswa sebesar 0,813. Dari hasil analisis tersebut diperoleh nilai probabilitas dari masing-masing variabel lebih besar dari 0,05 .

Berdasarkan hasil uji normalitas data tersebut menunjukkan bahwa semua variabel penelitian berdistribusi normal. Data hasil analisis adalah sebagai berikut. 
Tabel 7. Hasil analisis uji normalitas data One-Sample Kolmogorov Smirnov One-Sample Kolmogorov-Smirnov

\begin{tabular}{|c|c|c|c|c|c|}
\hline & & & $\mathrm{X} 1$ & $\mathrm{X} 2$ & $\mathrm{Y}$ \\
\hline$N$ & & & 70 & 70 & 70 \\
\hline \multirow{2}{*}{$\begin{array}{l}\text { Normal } \\
\text { Parameters }\end{array}$} & \multirow[t]{2}{*}{$a, b$} & Mean & 94.94 & 116.7 & 110.7 \\
\hline & & Std. Deviation & 8.526 & 10.19 & 15.22 \\
\hline \multirow{3}{*}{\multicolumn{2}{|c|}{$\begin{array}{l}\text { Most Extreme } \\
\text { Differences }\end{array}$}} & Absolut & .090 & .094 & .076 \\
\hline & & Positiv & .078 & .094 & .055 \\
\hline & & Negativ & -.090 & -.081 & -.076 \\
\hline \multicolumn{3}{|c|}{ Kolmogorov-Smirnov Z } & .752 & .785 & .636 \\
\hline \multicolumn{3}{|c|}{ Asymp. Sig. (2-tailed) } & .624 & .568 & .813 \\
\hline
\end{tabular}

a. Test distribution is Normal.

b. Calculated from data.

\section{Hasil analisis regresi ganda dan korelasi parsial}

Analisis regresi digunakan untuk mengetahui ramalan dan arah hubungan antara variabel penelitian kualitas pembelajaran siswa berdasarkan variabel kepemimpinan kepala madrasah $\left(\mathrm{X}_{1}\right)$ dan kemampuan mengajar guru $\left(\mathrm{X}_{2}\right)$ dan juga untuk menguji hpotesis yang diajukan dalam penelitian

Berdasarkan hasil perhitungan dengan menggunakan analisis regresi, diperoleh a sebesar 0,983 , b sebesar 0,565 dan c sebesar 0,480, sehingga persamaan regresi yang melukiskan skor ramalan kualitas pembelajaran siswa madrasah tsanawiyah di Kota Kendari berdasarkan variabel-variabel kepemimpinan kepala sekolah $\left(\mathrm{X}_{1}\right)$ dan kemampuan mengajar guru $\left(\mathrm{X}_{2}\right)$ adalah: $\mathrm{Y}=0,983+0,565\left(\mathrm{X}_{1}\right)+0,480\left(\mathrm{X}_{2}\right)$. Persamaan ini menunjukkan bahwa jika tidak ada kepemimpinan kepala madrasah dan kemampuan mengajar guru, maka kualitas pembelajaran siswa sebesar 0,983. Koefisien regresi sebesar 0,565 menyatakan bahwa setiap penambahan satu unit, kepemimpinan kepala sekolah $\left(\mathrm{X}_{1}\right)$ akan meningkatkan kualitas pembelajaran siswa madrasah tsanawiyah di Kota Kendari sebesar 0,565. Sementara itu, koefisien regresi kemampuan mengajar guru $\left(\mathrm{X}_{2}\right)$ madrasah tsanawiyah di Kota Kendari sebesar 0,480 menyatakan bahwa setiap penambahan satu unit kemampuan mengajar guru akan menaikkan kualitas pembelajaran siswa madrasah tsanawiyah di Kota Kendari sebesar 0,480. Hasil analisis data regresi ganda disajikan dalam Tabel 8 . 
Tabel 8 Harga-harga analisis regresi $\mathrm{Y}$ atas $\mathrm{X}_{1}$ dan $\mathrm{X}_{2}$

Coefficients a

\begin{tabular}{|c|c|c|c|c|c|c|c|c|c|}
\hline \multirow[b]{2}{*}{ Model } & & \multicolumn{2}{|c|}{$\begin{array}{l}\text { Unstandardized } \\
\text { Coefficients }\end{array}$} & \multirow{2}{*}{$\begin{array}{c}\begin{array}{c}\text { Standardized } \\
\text { Coefficients }\end{array} \\
\text { Beta }\end{array}$} & \multirow[b]{2}{*}{$t$} & \multirow[b]{2}{*}{ Sig. } & \multicolumn{3}{|c|}{ Correlations } \\
\hline & & B & Std. & & & & Zero- & Partial & Part \\
\hline \multirow[t]{3}{*}{1} & (Constant & .983 & 17.65 & & .056 & .956 & & & \\
\hline & $\mathrm{X} 1$ & .565 & .293 & .316 & 1.930 & .058 & .576 & .229 & .187 \\
\hline & $x_{2}$ & .480 & .245 & .322 & 1.961 & .054 & .577 & .233 & .191 \\
\hline
\end{tabular}

a. Dependent

Berdasarkan hasil uji $\mathrm{t}$ diperoleh nilai $\mathrm{t}$ untuk koefisien regresi kepemimpinan kepala madrasah sebesar 1,930 dengan signifikansi 0,058. Hasil ini menunjukkan bahwa prediktor b signifikan atau dengan kata lain terdapat hubungan yang positif dan signifikan antara kepemimpinan kepala madrasah dengan kualitas pembelajaran siswa madrasah tsanawiyah di Kota Kendari. Hasil tersebut didukung oleh koefisien korelasi parsial sebesar 0,229 atau sebesar 22,9 kontribusi relatif kepemimpinan kepala madrasah dengan kualitas pembelajaran siswa.

Berdasarkan hasil uji $\mathrm{t}$ diperoleh nilai $\mathrm{t}$ untuk koefisien regresi kemampuan mengajar guru sebesar 1,961 dengan signifikansi 0,054. Hasil ini menunjukkan bahwa prediktor c signifikan atau dengan kata lain terdapat hubungan yang positif dan signifikan antara kemampuan mengajar guru dengan kualitas pembelajaran siswa madrasah tsanawiyah di Kota Kendari. Hasil tersebut didukung oleh koefisien korelasi parsial sebesar 0,223 atau sebesar 22,3 persen kontribusi relatif kemampuan mengajar guru dengan kualitas pembelajaran siswa.

Temuan hasil penelitian ini menunjukkan bahwa secara keseluruhan kepemimpinan kepala madrasah memiliki hubungan dengan kemampuan mengajar guru madasah tsanawiyah di kota Kendari. Hasil penelitian ini sejalan dengan penelitian yang dilakukan oleh Versland dan Erickson (2017). Hal ini didukung oleh indikator yang nampak yaitu memahami secara jelas tentang tujuan yang hendak dicapai, menyusun rencana prosedur kerja secara periodik, memberikan bimbingan dan pengarahan dalam pelaksanaan tugas guru terutama tugas program instruksional, memberikan kebebasan kepada setiap personil untuk mengeluarkan ide dan saran sebagai masukan dalam pengambilan keputusan, menempatkan personil sesuai dengan kemampuan, berusaha menciptakan suasana kerja yang menyenangkan dan bertindak cepat dan tegas untuk mengoreksi dan mengarahkan bawahan dalam melaksanakan tugas. Hasil penelitian ini juga sejalan dengan yang dilakukan 
oleh Boonla dan Treputtharat (2014) yang menyatakan bahwa kepemimpinan kepala sekolah mempengaruhi kinerja guru. Demikian halnya dengan Ross and Gray (2006) yang menyimpulkan bahwa gaya kepemimpinan dapat meningkatkan komitmen guru.

Pola kepemimpinan akan berpengaruh bahkan menentukan terhadap kemajuan sekolah yang salah satunya dilihat dari kualitas pembelajaran siswa di madrasah. Kepala madrasah harus dapat memengaruhi, mendorong, membimbing dan mengarahkan personil madrasah khususnya guru dan siswa untuk berperan serta guna mencapai tujuan yang telah ditetapkan yaitu menciptakan suatu pembelajaran atau proses belajar mengajar yang berkualitas. Hal ini sesuai dengan hasil temuan penelitian yang menggambarkan bahwa kepemimpinan kepala madrasah memiliki hubungan dengan kualitas pembelajaran siswa.

Guru dan siswa sebagai orang yang terlibat langsung dalam proses pembelajaran harus dapat melaksanakan tanggung jawabnya dengan baik. Guru harus dapat menempatkan fungsinya dalam menciptakan, memelihara sistem organisasi kelas, sehingga siswa dapat memanfaatkan kemampuannya, bakatnya dan energinya sebagai pengajar. Guru perlu memiliki pengetahuan, keterampilan dan sikap mengajar di kelas secara efektif dan efisien, khususnya kemampuan dalam hal merumuskan tujuan pengajaran, kemampuan dalam penguasaan materi pelajaran dan kemampuan memilih metode mengajar secara tepat.

Hasil temuan penelitian ini menyatakan bahwa terdapat hubungan yang positif dan signifikan antara kemampuan mengajar guru dengan kualitas pembelajaran siswa. Penelitian ini sejalan dengan penelitian yang dilakukan Akiri dan Ugborugbo (2009) yang menyimpulkan bahwa kemampuan mengajar guru akan meningkatkan kemampuan belajar siswa. Guru sebagai pengajar dan pendidik harus memiliki pengetahuan, keterampilan dan sikap mengajar di kelas secara efektif dan efisien, khususnya kemampuan dalam hal merumuskan tujuan pengajaran, kemampuan penguasaan materi pelajaran, kemampuan memilih metode mengajar yang tepat. Seorang guru yang baik bukan hanya ditentukan oleh tingkat kepandaian atau ketinggian ilmu pengetahuannya saja, tetapi lebih banyak berkaitan dengan segi kemampuan mengajarnya sehari-hari. Yang dimaksud dengan kemampuan disini adalah kesanggupan dan kecakapan dalam aktivitas di dalam kelas, serta kemampuan konsep yang mencakup aspek kognitif, afektif dan psikomotor.

\section{Kesimpulan}

Berdasarkan uraian pada hasil penelitian dan pembahasan yang dipaparkan sebelumnya dapat disimpulkan bahwa secara umum responden 
menilai kepemimpinan kepala madrasah termasuk dalam kategori baik, walaupun masih ada sebagian kecil guru menilai bahwa kepemimpinan kepala madrasah sangat tidak baik. Secara umum, hasil penelitian ini memberi gambaran bahwa kemampuan mengajar guru berada dalam kategori baik, walaupun terdapat sebagian kecil responden yang memiliki kemampuan mengajar yang sangat tidak baik. Disamping itu, kualitas pembelajaran siswa berada dalam kategori baik, walaupun terdapat sebagian kecil responden yang menilai bahwa kualitas belajar siswa sangat tidak baik.

Berdasarkan hasil analisis statistik inferensial dengan menggunakan analisis regresi ganda terhadap hasil penelitian diketahui bahwa terdapat hubungan yang positif dan signifikan antara kepemimpinan kepala madrasah dan kemampuan mengajar guru dengan kualitas pembelajaran siswa madrasah tsanawiyah di Kota Kendari.

\section{Daftar Pustaka}

Abdurrahman, M. (2003). Pendidikan bagi anak berkesulitan belajar. Jakarta: Rineka Cipta.

Akiri, A. A., \& Ugborugbo, N. M. (2009). Teachers' effectiveness and students' academic performance in public secondary schools in Delta State, Nigeria. Stud Home Cumm Sci. Sel., 3(2), 107-113.

Antonakis, J., \& Day, D. V. (Ed.). (2018). The nature of leadership (Third Edition). California: SAGE Publications.

Atmodiwirio, S. (2000). Manajemen pendidikan Indonesia. Jakarta: PT Ardadizya Jaya.

Boonla, D., \& Treputtharat, S. (2014). The relationship between the leadership style and school effectiveness in school under the office of Secondary Education Area 20. Procedia - Social and Behavioral Sciences, 112, 991-996.

Hanaysha, J. (2016). Testing the effects of employee engagement, work environment, and organizational learning on organizational commitment. Procedia - Social and Behavioral Sciences, 229, 289 297.

Nawawi, H. (2002). Organisasi sekolah dan pengelolaan kelas sebagai lembaga kependidikan. Jakarta: Gunung Agung.

Qomar, M. (2007). Manajemen pendidikan Islam: Strategi baru pengelolaan lembaga pendidikan Islam. Jakarta: Penerbit Erlangga.

Ross, J. A., \& Gray, P. (2006). Transformational leadership and teacher commitment to organizational values: The mediating effects of 
collective teacher efficacy. School Effectiveness and School Improvement, 17(2), 179-199. DOI: 10.1080/09243450600565795

Rosyada, D. (2004). Paradigma pendidikan demokratis. Jakarta: Kencana

Suryadi, A., \& Tilaar, H. A. R. (1993). Analisis kebijakan pendidikan: Suatu pengantar. Bandung: Remaja Rosda Karya.

Usman, M. U. (2001). Menjadi guru profesional. Bandung: Remaja Rosdakarya.

Versland, T. M., \& Erickson, J. L. (2017). Leading by example: A case study of the influence of principal self-efficacy on collective efficacy. Cogent Education, 4(2), 1286765.

Wahjosumidjo. (1999). Kepemimpinan kepala sekolah: Tinjauan teoretik dan permasalahannya. Jakarta: RajaGrafindo Persada.

Yukl, G. (2017). Leadership in organizations (Seventh edition). (A. Cahayani, Pnjmh). Jakarta: PT. Indeks. 